EIS 11/2017

\section{Regional} cooperation within the Eastern Partnership

\section{Submitted}

04/2017

Accepted for publication 08/2017

\title{
Małgorzata Zajaczkowski
}

Warsaw School of Economics, Poland, al. Niepodległości 162, 02-554 Warsaw, Poland

e-mail address: mgraci@sgh.waw.pl

$\Gamma$ crossef http://dx.doi.org/10.5755/j01.eis.0.11.18428

Abstract

The aim of the paper is to present and analyze the problem of cooperation between the Eastern partners of the European Neighborhood Policy (ENP). The problem is that current regional cooperation is insufficient and superficial what makes common arrangements impossible to attain. It resulted from weak economic relations and low level of interdependence among the Eastern partners. Moreover the biggest obstacles are looming interstate or local political or military conflicts in the Eastern Europe and Southern Caucasus which have been dominating political and economic scenes of that regions since the changes of the 1990. The paper's aim is to examine difficulties that prevent the countries from engaging in wider economic cooperation and find areas for development of new regional initiatives. Major question is whether the ENP has contributed to enhancing of cooperation among the Eastern partners? The answer is twofold. On the one hand the EU's initiative has brought about to establishing institutional and financial framework for developing regional initiatives and on the other, the lack of stable economic and political relations and unresolved conflicts have prevent the Eastern neighbors from engaging in genuine cooperation.

KEYWORDS: European Union (EU), Eastern Partnership (EaP), European Neighborhood Policy (ENP), regional cooperation, Deep and Comprehensive Free Trade Areas (DCFTA).

\section{Introduction}

Development of regional cooperation is of utmost importance to the functioning of the European Neighborhood Policy (ENP). It is especially significant across the EU's external borders and among the EU's neighbors themselves, specially that are geographically close to each other. The idea behind the ENP and its Eastern dimension provides the EU' neighbors with two options: first - an alternative to the EU's membership through offering the countries comprehensive and deep economic and political cooperation, second - the membership perspective through engaging the partners in a long-run economic, social and political reforms.

The problem is that current regional cooperation is insufficient and superficial what makes common arrangements impossible to attain. The Riga summit on Eastern Partnership (EaP) in 2015 showed broadening split between those partners who wish to join the EU and those who want to stay apart and benefit from bilateral economic cooperation with the EU. Therefore the aim of the paper is to present the root causes of restrained intra-regional cooperation and indicate the conditions in which closer economic and political relations between the Eastern partners would unfold. Thus it leads to the general question on whether the ENP initiative has fulfilled its objectives and contributed to enhancing of cooperation among the EaP countries.

European Integration Studies No. $11 / 2017$

pp. $138-147$

DOI 10.5755/j01.eis. 0.11 .18428 (c) Kaunas University of Technology

The paper is based on selected EU's documents related to ENP as well as the subject literature referring to assessment of the Eastern Partnership initiative. It is limited to key policy actions 
undertaken both by the EU and the Eastern partners themselves. It resulted both from changes in the ENP agenda as well as internal turbulences in the Eastern Europe and the Southern Caucasus. The research comprises three parts. In the first section there was depicted general geopolitical overview of the ENP and the Eastern dimension. Second part concentrates on hardships which prevent the partner countries from continuing bilateral and multilateral cooperation. The last part focused on sectoral initiatives which the partner countries were managed to established with financial support from the EU.

In 2009 the EU has launched the Eastern Partnership which was to strengthen the Eastern dimension of the ENP. The offer was aimed at six countries from Eastern Europe and Southern Caucasus (i.e. Armenia, Azerbaijan, Belarus, Georgia, the Republic of Moldova and Ukraine) to address their specific needs of the regions in a multilateral forum. The EaP has created more complex perspective for the ENP with sustaining its overriding objectives such as enhancing of cooperation and granting of accession to the EU market under bilateral action plans (EPRS, 2016).

The overall ENP program provided an institutional framework for the EU to negotiate its relationship with the neighbors after the 2004 enlargement with a perspective of association agreements. It embraced 16 Eastern and Southern neighbors. The main objective was to avoid the emergence of new dividing lines between the enlarged $\mathrm{EU}$ and its neighbors by engaging in the negotiation of reform priorities leading to good governance, rule of law, trade liberalization and civil society representation in the partner countries. The ENP was to go beyond traditional financial assistance provided to the neighboring countries and was assumed to be better suited to the challenges in particular regions. Under the ENP there were issued two pivotal programs which were to reinforced each of its regional dimensions: the Eastern Partnership and the Union for the Mediterranean. Both initiatives were to undercut of political instability and economic fragility throughout the regions. For the EU the crucial goal was to support stability along the European periphery while enhancing cooperation with the most advanced and eager neighbors.

The ENP's institutional framework of cooperation was based on a commitment to fundamental values such as democracy, the rule of law and respect for human rights, market economy, sustainable development and good governance. The idea of how to treat the countries left after the downfall of the Soviet Union was one of the biggest challenge for the EU's foreign policy. After the admission of the Central European Countries to the EU in 2004 and 2007 the Union decided to launch a program which would provide the EU's Eastern neighbors with an alternative to membership a set of incentives for engaging in economic, social and political reforms. The EU decided to promote regional cooperation under the EaP initiative instead of bringing the countries closer to the accession formula.

Under the ENP Instrument for 2014-2020 the EU has allocated to the regional projects within the EaP between 741 and $906 \mathrm{mln}$ EUR. Most of the funds were dedicated to enhancing intra-regional economic cooperation among the Eastern partners as their economic relations have been at a relatively low level. Deeper market integration would help stimulate economic growth in the regions but might also bring political and social benefits such as reconciliation and confidence building. The crucial tool for development mutual contacts became the agreements on Deep and Comprehensive Free Trade Areas (DCFTA) with Ukraine, Georgia and the Republic of Moldova as a part of Association Agreements (AAs). This universally used instrument of economic integration might contribute to building sound trade relations in the region and boosting foreign direct investments which would lead to job creation and long-term growth. The EU's ultimate goal for the DCFTA associate countries was to create a wider regional free trade area based on the WTO rules and international multilateral agreements (EC, 2015).

For these Eastern partners who did not want to engage in negotiations for a DCFTA the EU offered more flexible mechanism such as Agreements on Conformity Assessment and Acceptance

\section{ENP in brief}




\begin{tabular}{|c|c|c|c|c|}
\hline \multirow{6}{*}{$\begin{array}{r}\text { Table } 1 \\
\text { Initiatives designed } \\
\text { by the EU }\end{array}$} & \multicolumn{4}{|c|}{ Thematic platforms } \\
\hline & $\begin{array}{l}\text { Democracy, good governance } \\
\text { and stability }\end{array}$ & $\begin{array}{l}\text { Economic integration and } \\
\text { convergence with the EU policies }\end{array}$ & $\begin{array}{l}\text { Energy } \\
\text { security }\end{array}$ & $\begin{array}{l}\text { Contacts } \\
\text { between people }\end{array}$ \\
\hline & \multicolumn{4}{|c|}{ Flagship initiatives } \\
\hline & \multicolumn{4}{|c|}{$\begin{array}{l}\text { integrated border management; } \\
\text { regional electricity markets, } \\
\text { energy efficiency and renewables; } \\
\text { natural and man-made disaster prevention; } \\
\text { small and medium size enterprises; } \\
\text { environmental governance }\end{array}$} \\
\hline & \multicolumn{4}{|c|}{ Non-governmental initiatives } \\
\hline & Civil Society Forum & $\begin{array}{l}\text { Parliamentary dimension } \\
\text { (EURONEST) }\end{array}$ & $\begin{array}{l}\text { Committ } \\
\text { for Local }\end{array}$ & $\begin{array}{l}\text { gion's Proposal } \\
\text { gional Assembly }\end{array}$ \\
\hline
\end{tabular}

Source: J. Boonstra, N. Shapovalova, (2010), p. 6.

(ACAAs), which would allow free movement of industrial products in specific sectors (EC, 2015). In the absence of regular form of cooperation between the partner countries the EU has offered four thematic platforms which covered: (1) democracy, good governance and stability, (2) economic integration and convergence with EU policies; (3) energy security and (4) contacts between people. In 2009 it was held first inaugural ministerial meeting which launched the two-year work programs for each of the areas. There were established the so-called flagship initiatives: integrated border management; regional electricity markets, energy efficiency and renewables; natural and man-made disaster prevention; small and medium size enterprises and environmental governance (Boonstra, Shapovalova, 2010).

Much attention was paid to parliamentary cooperation as well as collaboration with non-state actors. For that purpose there were appointed the EU-Eastern partners parliamentary assembly EURONEST and Civil Society Forum. The intention of parliamentary cooperation was to improve mutual relations between the partner countries national assemblies and the representatives of the EU Parliament. The objective was to strengthen the EaP thematic platforms and flagships initiatives. The Civil Society Forum established in 2009 was designed to represent civil society actors from the EU, partner states and the third countries. Moreover the EU's Committee of Regions took and initiative to establish local and regional assembly in Eastern Europe and Southern Caucasus (Table 1). There were to o serve as thematic platforms to establishing and maintaining regular dialogue and cooperation in areas of greatest importance for the local and regional authorities (Boonstra, Shapovalova, 2010). The process of building cooperation was to involve state institutions (local and regional authorities) as well as non-governmental actors.

The hardships of cooperation
Promotion of regional cooperation within the ENP has become a key objective, however at the very beginning the focus was put on other areas. The ENP was based much more on developing bilateral relations than multilateral cooperation in the regions. It resulted from a number of hardships and impediments that the partner countries have encountered during their long term relations. An attempt to remedy the situation was the initiative of the Union of Mediterranean and the Eastern Partnership. Thus there were established two regional platforms which were first, to strengthen the overall ENP program and second, to improve intra-regional cooperation. The latter would make much more positive developments for the partner countries since most of the problems are regional and cannot be effectively addressed on bilateral basis (Tkeshelashvili 2015, p. 29-30). 
The EaP programme assumed to "strengthen relations among the partners themselves, contributing to the exchange of information and experience in a whole range of reform areas and to the adoption of common standards" (Euronest 2016). On the other hand achieving the goal has appeared to be a complicated task as a large number of Eastern partners have been affected by armed or frozen conflicts which hampered economic, social and political transformation as well as regional cooperation, stability and security. The EU's concept of promotion of intra- regional cooperation came from the pattern of economic integration among Central and Eastern European countries and in the Western Balkans. These were the good examples for deepening economic integration among the partners which were culturally and historically closely linked with each other. However the changing geopolitical situation in the regions of Eastern Europe and Southern Caucasus has not been favorable to establishing permanent cooperation framework.

The EU was particularly interested in extending its security area by expressing its willingness to resolve interstate conflicts and to obstruct further disputes in the regions. Due to their negative impact on the economy the conflicts and political disputes impede economic cooperation and political dialogue. Therefore the EU was very much interested in overcoming negative tendencies in policy of the EaP partners.

The open or frozen disagreements in the Eastern Europe and Southern Caucasus have been dominating political and economic scenes of that regions since the changes of the 1990. Some of the conflicts date back to the period of functioning the Soviet Union. However contribution to their peaceful solution is a prerequisite to undertaking any further steps. The frozen military strives have been ongoing between Armenia and Azerbaijan over Nagorno Karabakh, Georgia and Russia over South Ossetia and Abkhazia. Ukraine and Moldova are enmeshed in internal conflicts where Russian plays a pivotal role. Since 2014 Moscow has been running military actions in the Eastern Ukraine and it has been engaged in the process of autonomy of Transnistria which finally may result in taking control over the Moldavian territory. In all cases the problem have arisen from ethnic, national and religious differences and the interference of external powers such as Russia. Turkey or Iran.

In case of the conflict between Armenia and Azerbaijan over the Nagorno Karabakh both countries were called to enhance diplomatic efforts and intensified bilateral dialogue. Unfortunately not much so far has been achieved while in the first half of 2016 the situation exacerbated substantially. It proofs again that the ENP has not brought enough incentives for the partners to overcome the crisis. The EU was again criticized for the inconsistent policy and the lack of bargaining power in the region. The Western Europeans were blamed for an insufficient use of their economic and political power by using the principle of stronger conditionality.

In case of Moldova the most important problem is to resolve the conflict in Transnistria. A peaceful settlement between the Republic of Moldova and territory of Transnistria is of utmost importance for socio-economic development of the country and for improving good relations with neighboring states. The conflict is situated in a broader geopolitical bargaining process involving Russia and the EU with special interest of Romania and Ukraine. The latter participates in international negotiations on the status of Transnistria inside Moldova alongside with Russia and the OSCE. Moreover Kyiv holds peacekeeping troops in the secessionist area.

The role of Ukraine in the conflict over Transnistria is ambiguous. On the one hand is seems that the settlement of the crisis is beneficial because it can contribute to improving regional stability and Ukraine's long-term European and Euro-Atlantic aspirations. On the other hand serious interest groups in Ukraine benefit from smuggling, trafficking and export of arms passing mainly through Ukrainian land and sea borders. That kind of cooperation was also profitable for the survival of Transnistria, specially after the new Moldovan customs treaty was introduced in 2001 and Ukraine did not stop accepting exports from Transnistria (Popescu, 2005, p. 25). 
Major obstacle to Ukrainian recover is its conflict with Russia. It has weakened Ukrainian economy and prevented from developing cooperation with its neighbors. Ukraine is currently a long way away from stability after an annexation of its territory of Crimea by its powerful neighbor and a perpetual internal political turmoil. In these circumstance there is difficult to develop sound and long-term cooperation with its neighbors. Southern Ukraine is still facing a threat of Russian military intervention and the central government does not have sufficient support from political parties and Ukrainian society. Key attention is paid to quick economic recovery with strong assistance of the EU's institutions and programs.

The frozen conflicts in the area of EaP have confirmed that Eastern Europe and Southern Caucasus remain a volatile area despite a number of institutional framework for cooperation provided by the EU. The continuing conflicts in Georgia (South Ossetia and Abkhazia), Azerbaijan and Armenia (over Nagorno-Karabakh region), as well as Moldova over Transnistria make the current situation under the ENP framework even more fragile (Jankowski, 2014). In all above mentioned cases Russia plays a pivotal role of revisionist power by precluding the EaP partners from strengthening their ties with the EU.

Different expectations and contradictory visions

Different expectations and varying visions of the partner countries towards the EaP have led to partition within the group of counties and failure of the initiative. The root-causes of the situation were much older than the ENP initiative itself due to each of the neighbor has had different strategic visions towards the region and different policy. Thus the EU's approach based on treating all partners equally turned out to be a mistake.

The six member-states have divided into two distinct groups, and in some opinion even three (Giragosian 2015, p. 10). The problem is that within each of the group there are looming a number of difficulties and disagreements in terms of reform performance and the EU's membership aspirations. The first group is consisting of these partners which have ultimately signed the Association Agreements (AAs) and have expressed its intension to accede the EU in the future. It concerns Georgia, Moldova and Ukraine though their Western political orientation has been fluctuating over time. The second group comprises Belarus, Armenia and Azerbaijan which have not decided to conclude their AAs.

In case of Azerbaijan its government has not even expressed an interest in negotiating the AAs, and its commitment into the EaP was marginal. Therefore the role of Azerbaijan within the framework of the ENP has been secondary which corresponded to the EU's poor activity in pulling the authorities in Baku on the European side (Alieva 2015, p. 12). The Azerbaijan position originated from its importance as a leading provider of gas and oil in the Southern Caucaus, particularly in the context of Russian aggression to East Ukraine. As the EU's policy towards the government in Baku was based on energy interests its engagement in reforms has been diminished and the European integrationist trend has heavily decreased. The EU has failed to offer the oil-rich economy something more than a vague perspective of the access to the EU market and visa facilitation.

The Armenian case is much more complicated. The government has admittedly declared its intension to integrate with the EU, but because of the Moscow's political and economic pressure it has withdrawn from initial promises. In 2013 Armenia has decided to abandon its planned AAs with the EU in return to joining the Russian-led Eurasian Economic Union. Its turn resulted from the risk of a minor engagement of the EU in the Southern Caucasus and the rising demands from Russia. The danger for Armenia stems from greater isolation and a threat of becoming a state subordinated to Russian authorities (Giragosian 2015, p. 11).

The change in political and economic circumstances indicates the fact that in 2006 both Azerbaijan and Armenia ENP's Action Plans had a clause on EU's aspiration. Most of the pools showed significant support for European integration (Alieva 2015, p. 15). Nevertheless, the government in Ye- 
revan has put its political and economic survival on strategic partnership with Russia as it is a key trading partner and the deliverer of vital supplies of energy. Moscow is also the principal source of Armenian security, providing much needed military equipment and political support (German, 2012, p.149-176). Armenia is under economic embargo of Azerbaijan, but it maintains close economic and security relations with Georgia (Babayan, 2012, p. 49). Therefore Georgia is seeking to play a catalyzing role in the region having good relations both with Armenia and Azerbaijan.

For Belarus its participation in the ENP allows the government in Minsk to benefit financially from the EU's program. In the absence of a bilateral agreement the Belarus engagement in the Eastern Partnership legitimates relations with the EU. It also allows for maintaining a platform for any intergovernmental contacts and civil society cooperation (Preiherman 2015, p. 18). Close political and economic relationships with Russia give Belarus strong support from powerful neighbor but on the other had a danger for its national sovereignty. Its participation in the Eurasian Union together with Russia and Kazachstan is not an alternative for regional economic projects but a geopolitical and ideological imperative imposed by Russia. The more serious the frictions between the EU and Russia are the more difficult is for Belarus to balance between the two influencing neighbors. So far its capability to maintain an impression on independent policy have been quite successful. Instead bilateral relations with the EU have let the government in Minsk to gain more bargaining power against Russia.

Moldova was one of the most advanced partner on the way to European integration by signing in 2014 its AAs and concluding negotiation on DCFTA. The question is whether the state will be able to implement the provisions of both documents since the last parliamentary elections have emerged new political forces skeptical to European integration. The problem rests also in decreasing support of Moldavian society towards the European membership. Instead there has been rising an endorsement for Moldova's accession to the Eurasian Union, which is very much assisted by Russia. Moscow opposes Moldova's rapprochement to the EU by using political pressure, trade blockades, energy threats and media propaganda (Chirila, 2015, p. 36).

The presence of Ukraine within the ENP has been marked by its military conflict with Russia. From the Ukrainian perspective its further engagement in the initiative should be clearly reaffirmed by its prospect of the EU's membership. Otherwise it may drop reform hardships and find itself again in the orbit of Russian influences. In order to face up to Russian demands Ukraine requires an urgent access to European market, inclusion in European energy system and a visa free regime.

In case of Georgia its enthusiastic approach to European integration has been chilled by the EU's pragmatic policy. Georgia has not been yet offered a formal candidate perspective despite its staunchest support towards the EU and engagement in the reform process. Because of the evident division within the EaP for those who have signed the AAs and the DCFTA and those partners who have pulled back, Georgia advocates the idea of forming a separate group in the form of EaP $(3+1)$. It would let the most interested partner countries to deepen their cooperation such as exchange of the experience on reform, synchronizing of regulatory policy reforms (Gogolashvili 2015).

The failure of enhancing cooperation within the Eastern dimension of the ENP stems from several reasons. First, the argument about the commonalities between the six member countries is too far-reaching. Despite the fact that partners are combined by common post-soviet historical legacy their different interests and expectations prevent them from broadening and deepening mutual relations. Second, their communist heritage can both unite and divide. They are bound by common history and close political, economic and cultural connections enforced by the former Soviet Union, which on the one hand may serve as a foundation for collaboration, but on the other restrain this cooperation. Third, the ENP was seen by the partners as a platform for the advancement of their political and economic reform agenda rather than as a significant regional platform (Tkeshelashvili 2015 , p. 30). The only regional sector that has performed well so far was the platform of civil society. 
The prospects for cooperation
Major initiatives which has led to develop intra -regional cooperation within the EaP was established by the EU. They have gained institutional and financial support from the EU and were to encourage the partner countries to keep on the process.

The EU has established several cross-border programs that have incorporated the countries from the Eastern dimension of the ENP. Most of the actions presented below have been launched by 2014. The priority areas for bilateral and multilateral cooperation were: (1) energy, (2) border management, (3) transport and (4) environment. Some progress has also been achieved in the area of educational cooperation.

Ad. 1. In energy sector the EU has launched in 2009 the Eastern Europe Energy Efficiency and Environment Partnership (E5P), which was first addressed to Ukraine and next extended in 2013 to Moldova, Georgia, Armenia. The aim is to unite the Eastern Partnership countries, European Commission and other bilateral donors in the region to coordinate and accelerate the implementation of energy efficiency and environmental projects. Moreover some progress was achieved within the specialized programs such as the INOGATE and the 'Covenant of Mayors' initiative targeted municipal level to better energy efficiency in Eastern partner countries. Regular dialogue on energy is taken at the foreign ministers plenary sessions that were held in Baku in 2014 and Riga in 2015.

$\mathrm{Ad} 2$ 2. In border management area the EU has initiated the support program for territorial cooperation to improve capacity building, communication and awareness-raising activities in all the EaP partners. The program aims to promote cross-border cooperation between border regions of the EaP partner countries. It seeks to boost the capacity of local and regional actors in the bordering regions of partner countries that would help them implement cross-border initiatives without the involvement of EU member states. In practice the partner countries obtain technical assistance to develop the capacity of state and non-state actors (Panorama, 2013, p. 66). The objective is to lay a foundation for territorial cooperation programs established at 4 borders: between the Ukraine and Belarus, Ukraine and Moldova, Georgia and Armenia, Georgia and Azerbaijan. The participation on the programs is open for local, regional and national authorities as well as for NGOs.

As a significant aspect of EU-led regional cooperation and good neighborly relations the EU has funded in 2007 a South Caucasus Integrated Border Management Program that included the partner states from the region. Its aim was to help the partners to boost their security and facilitate the cross-border movement of people and goods. Similar initiative has been established separately for Ukraine and Moldova. A capacity building projects under the integrated border management program was focused on specialized training and the fight against corruption, and human rights aspects.

Ad. 3. As far as transport is concerned the EU has established the regional transport cooperation platform which was concentrated on rail and road priority projects, but also included the improvement of motorways of the sea, hinterland connections, logistics centers and the safety and security of maritime and aviation transport. The partners have committed to implement decisions taken at the Eastern European transport ministers meeting, which focused on including inland waterways in the transport network, but also dealt with EU road safety policy, including the adoption of the roadworthiness package. Two regional projects on road safety were launched in January 2014, supporting countries on road design, awareness campaigns and enforcement of legislation (EC, Implementation, 2015).

Ad. 4. Under the environment framework cooperation was designed to pursue via the flagship initiative entitled "Towards a Shared Environmental Information System Program (SEIS) in the ENPI Region', as well under the other regional and local programs. They were aimed at improving the quality, timeliness and availability of environmental information and to set up an environmental information system in line with the EU's shared environmental information system. There was also established a number of specialized programs on nature protection sites (the 
Emerald Network), on forest law enforcement (FLEG), on obsolete pesticide and other hazardous waste (EC, Implementation, 2015). One of the tangible achievement in the environmental area was the conclusion of the regional program on Air Quality Governance, which provided further assistance on pollution prevention permits (EC, Implementation, 2015). Moreover in all 6 EaP countries there were introduced a disaster risk assessments based on the EU risk assessment methodology. The results of the operation were presented as an electronic risk atlas and were available at national, sub-regional and regional level. All activities have brought the partner countries progressively closer to the EU civil protection mechanism and contribute to the enforcement of regional cooperation in that field. The disaster risk protection started in Belarus, Georgia and in the South Caucasus countries.

Good results have been achieved in the area of education. There were initiated various international programs on higher education, young people, culture and research. For the purpose of development of regional cooperation substantial progress was made in the initiative of regional Torino Process. All $6 \mathrm{EaP}$ countries had an opportunity to share their achievements in the field of vocational education and training, identified areas for potential regional cooperation. In order to develop research and innovation network the EU has given an open access for researchers and innovators from the EaP under the "Horizon 2020". The willingness to join the program was declared by Moldova, Ukraine, Georgia and Armenia.

Successful conclusion of the EU-led programs require greater support from the partner countries both at the level of government officials as well as regional political leaders. Any effort to overcome the stalemate in the region by initiating projects and join enterprises needs substantial financing and political assistance. In order to trigger intra-regional cooperation all stakeholders should enhance their commitments which in practice may lead to the following actions:

- First, the EU shall offer the most advanced partner countries in terms of systemic reforms such as Ukraine, Moldova and Georgia a perspective of the EU's membership. The current offer has discouraged these partners to take strong efforts on improving their neighboring relations, particularly in a situation when a conflict was a good motive for internal political use. The partners with poor transformation achievements such as Belarus, Armenia and Azerbaijan would except a 'privileged relationship' based on greater economic assistance.

- Second, the EU should give more support for those EaP partners which reform more. Those countries which meet the required criteria should be rewarded in a manner as the EU has done in the case of Western Balkans states. The implementation of the principle "less for those who reform less" would reinforce the efficiency of the differentiated integration approach (Nicolescu, 2013, p. 4). The partners should be assessed in accordance to their individual merits what seems to be the right respond for the cases in which the principle of conditionality does not work.

_ Third, The ENP agenda should be flexible in order to adapt to new circumstances. External and internal changes in partner countries have reversed the context of the ENP and its Eastern Dimension. It is primary referring to frozen military conflicts and recurring political turmoil but also the role of Russia and Turkey whose contradictory interests and different positions have affected directly the policy of the partner countries. This problem is closely related to international position of the $\mathrm{EU}$ and its capacity to take effective response in a conflict situation.

It has passed eight years since the Eastern Partnership (EaP) was launched by the Polish-Swedish tandem in 2009. The initiative was expected to stimulate changes in Eastern Europe and Southern Caucasus by bringing forward internal reforms and enhancing intra-regional cooperation. The EaP initiative was to reinforce the ENP for which the good neighborly relations constituted the bedrock of its further functioning. The idea of promoting regional cooperation was 
based on the EU's commitment to protect its interests and maintain stabilization at the EU's external frontiers while offering the partners economic and social benefits.

The ENP has hardly committed to boost intraregional cooperation among the Eastern partners. It is one of the most criticized aspect of the ENP which was neglected both by the Europeans and the partners countries. Most institutional and economic efforts taken by the EU and its members have not brought expected results. An increase of nationalist sentiments in the most ENP partners, military conflict at the Eastern border of Ukraine, the escalation of hostile and military operations between Azerbaijan and Armenia in Nagorno-Karabakh are the most evident examples of the EU's failure. It was not repeated a success of the EU' impact on Central and Eastern Europe and the Western Balkans. The EU's strategy relied on political dialogue and economic assistance has not been sufficient incentive to change. Admittedly there were some area of cooperation within the framework of the EU-led programs but the escalation of military conflicts and ongoing political tensions have dwarfed the symptoms of cooperation.

\section{References}

Alieva L. (2015) The European Neighborhood Policy and Azerbeijan: When Soft Power and Security are tightly related in: Inayeh A., Forbrig J. ed. Reviewing the European Neighbourhood Policy: Eastern Perspectives, "Europe Policy Paper 4/2015", The German Marshall Plan of the United States, Washington,

Babayan, N. (2012). "Fear or Love Thy Neighbor"? The EU Framework for Promoting Regional Cooperation in the South Caucasus', Journal of Contemporary European Research. Volume 8, Issue 1,

Belarus - EU (2016), an Overview, European External Action Service, (EEAS), downloaded from http://eeas.europa.eu/delegations/belarus/projects/overview/index_en.htm (21.04.2017)

Boonstra J., Shapovalova N., (2010) The EU's Eastern Partnership: One year backwards, "FRIDE Working Paper", No 99, pp. 6-7.

Chirila V. (2015) Moldova: More Focus, Flexibility, and Visibility for the European Neighborhood Policy in: Inayeh A., Forbrig J. ed. Reviewing the European Neighbourhood Policy: Eastern Perspectives, "Europe Policy Paper 4/2015", The German Marshall Plan of the United States, Washington

European External Action Service (EEAS) (2016), The ENP, downloaded from https://eeas.europa. eu/topics/european-neighbourhood-policy-enp

Euronest Parliamentary Assembly on EU multiannual financial perspectives and their impact on economic cooperation among Eastern Partnership countries, (2016/C 193/02), 22 March 2016.

EU-Moldova Action Plan, 2004, European External Action Service, (EEAS) downloaded from http:// eeas.europa.eu/enp/pdf/pdf/action_plans/moldova_enp_ap_final_en.pdf

European Neighborhood Policy at a glance (2016), European Parliamentary Research Service, EPRS, October, downloaded from http://www.europarl. europa.eu/RegData/etudes/ATAG/2016/593478/ EPRS_ATA(2016)593478_EN.pdf (23.04.2017)

European Commission (EC) (2015) Implementation of the European Neighborhood Policy. Eastern Partnership Implementation Report, SWD(2015) 76 final, Brussels, 25.3.2015,

European Commission (EC) (2015) Review of the European Neighbourhood Policy, Joint Communication to the European Parliament, The Council, The European Economic and Social Committee and the Committee of the Regions, SWD(2015) 500 final\}, 18.11.2015

EU-Ukraine Action Plan (2008), Join Evaluation Report, European External Action Service, (EEAS) downloaded from http://eeas.europa.eu/ukraine/ docs/ukraine_eu_joint_evaluation_2008_en.pdf

German T. (2012), Regional Cooperation in the South Caucasus. Good Neighbors or Distant Relatives, Routledge,

Giragosian R. (2015), The European Neighbourhood Policy: an Armenian perspective, in: Inayeh A., Forbrig J. ed. Reviewing the European Neighbourhood Policy: Eastern Perspectives, "Europe Policy Paper 4/2015", The German Marshall Plan of the United States, Washington,

Gogolashvili K. (2015), Reform of the ENP and the Eastern partnership - a view from Georgia http:// www.europeanleadershipnetwork.org/reform-of- 
the-enp-and-the-eastern-partnership--a-viewfrom-georgia_2763.html (02.05.2017)

Inayeh A., Forbrig J. ed. (2015) Reviewing the European Neighbourhood Policy: Eastern Perspectives, "Europe Policy Paper 4/2015", The German Marshall Plan of the United States, Wasgington,

Jankowski, D. P. (2014) Russia - Ukraine conflict: lessons for Europeans, downloaded from http:// foreignpolicyblogs.com/2014/09/05/the-russia-ukraine-conflict-lessons-for-europeans/

Nicolescu A. (2013) Eastern Partnership Roadmap 2012-2013 and the European Enlargement Strategy: Main Challenges to the Conditionality and Differentiated Integration Principles, Istituto Affari
Internazionali, DOCUMENTI IAI 13 | 11 - November, Panorama of EU Regional Programmes and Projects. Eastern Partnership and Russia. (2013), EC Directorate General Development and Cooperation - EuropeAid, European Commission,

Popescu N. (2005), Settling Conflicts in the neighborhood, Occasional Paper, No 60, October 2005, Institute for Security Studies, Paris

Tkeshelashvili E. (2015), European Neighbourhood Policy Review: Comprehensive Reset or Rebranding Initiative? in: Inayeh A., Forbrig J. ed. Reviewing the European Neighbourhood Policy: Eastern Perspectives, “Europe Policy Paper 4/2015", The German Marshall Plan of the United States, Washington.

This research project has benefited from funding under the Polish "National Science Centre" (NCN) grant titled "European Neighbourhood Policy: (multi-level) governance, the reform process and the prospect of enhanced cooperation in the region", OPUS/HS5, No. 2013/09/B/HS5/04534.

\section{ZAJACZKOWSKI MAŁGORZATA}

$\mathrm{PhD}$

\section{About the author}

Warsaw School of Economics, Institute of International Studies

\section{Fields of research interests}

European integration, Transatlantic relations, WTO, Development cooperation

\section{Address}

Al. Niepodległości 162, 02-554 Warsaw, Poland

Tel. +48225649406 